\title{
Molecular characterization and evaluation of antimicrobial susceptibility of enteropathogenic $E$. coli (EPEC) isolated from minas soft cheese
}

\author{
Caracterização molecular e avaliação da suscetibilidade antimicrobiana de cepas enteropatogenicas \\ de E. coli (EPEC), isoladas de queijo minas frescal
}

\author{
Mariana Tavares DIAS ${ }^{1 *}$, Silvia Maria Lopes BRICIO ${ }^{1}$, Davi Oliveira ALMEIDA ${ }^{1}$, \\ Luiz Antônio Trindade OLIVEIRA ${ }^{2}$, Ivano de FILIPPIS ${ }^{1}$, Victor Augustus MARIN ${ }^{1}$
}

\begin{abstract}
Foodborne disease caused by microorganisms is a problem of public health. Minas soft cheese is a national product manufactured using simple technology; it has high level of acceptance in the country making its production an important economic activity. Many microorganisms may be present in foods including the bacterium Escherichia coli (E. coli). Overall, E. coli is a harmless commensal bacterium; however, some strains may have a pathogenic potential. Several outbreaks of foodborne diseases associated with consumption of contaminated cheese have been reported, and the presence of pathogenic strains of $E$. coli has increased. The objective of this study was to isolate, evaluate the antimicrobial susceptibility, and characterize, by Multiplex PCR, the pathogenic E. coli strains isolated from Minas cheese commercialized in Rio de Janeiro. Thirty samples were analyzed and five strains of E. coli (EPEC) were identified. The assessment of antimicrobial susceptibility revealed $40 \%$ of the isolates resistant to ampicillin and $40 \%$ with intermediate resistance to ampicillin-sulbactam combination. These findings are a warning signal to health authorities since Minas cheese is a ready to eat food product, and therefore should not pose health risks to the population. Keywords: minas soft cheese; EPEC; antimicrobial.
\end{abstract}

\begin{abstract}
Resumo
Doenças transmitidas por alimentos (DTA), causadas por microrganismos, representam um importante problema de saúde pública. O queijo Minas Frescal é um produto nacional, de tecnologia simples e elevada aceitação no País, tornando sua produção uma importante atividade econômica. Muitos microrganismos podem estar presentes neste alimento e, entre eles, destaca-se a bactéria Escherichia coli (E. coli). De modo geral, E. coli é um comensal inofensivo, entretanto, algumas cepas podem apresentar potencial patogênico. Diversos surtos de DTA, associados ao consumo de queijos contaminados, têm sido relatados e a presença de cepas patogênicas de E. coli cada vez mais observada. Este estudo teve como objetivo isolar, avaliar a suscetibilidade antimicrobiana e caracterizar molecularmente, através da Multiplex PCR, as cepas patogênicas de E. coli, isoladas de queijo Minas Frescal comercializado no município do Rio de Janeiro. Trinta amostras foram analisadas e cinco cepas de E. coli enteropatogênica (EPEC) identificadas. A avaliação da suscetibilidade antimicrobiana revelou $40 \%$ de resistência à ampicilina e $40 \%$ de perfil de resistência intermediária à associação ampicilina-sulbactam. Tais resultados representam um alerta para as autoridades sanitárias, uma vez que este alimento é um produto de pronto consumo e, portanto, precisa ser inócuo para que a saúde da população não seja colocada em risco.

Palavras-chave: queijo minas frescal; EPEC; antimicrobianos.
\end{abstract}

\section{Introduction}

In the last decades, human nutrition has been a reason of concern worldwide. Pursuit of healthy eating habits has led to increased consumption of milk and lactic derivatives (SILVA; SOUZA, 2006).

Minas soft cheese is a typical national product manufactured with simple technology production and has wide acceptance in the country (SILVA; SOUZA, 2006). This product contains a large amount of water (43\%) and low $\mathrm{pH}(5.1-5.6)$ (FREITAS et al., 1993), and its microbiological standards have been established by the Technical Regulation of Identity and Quality of Minas Soft Cheese (BRASIL, 1997).

Despite the legal requirements for milk intended to be used for cheese production to be sanitized through appropriate methods and subjected to pasteurization or equivalent heat treatment (BRASIL, 1974), the commercialization requirements of Minas soft cheese are not thoroughly followed, especially by small industries and homemade cheese production (BRAMLEY; McKINNON, 1990). The handmade production of Minas soft

\section{Received $1 / 1 / 2011$}

Accepted 5/7/2012 (005208)

${ }^{1}$ Setor de Alimentos, Departamento de Microbiologia, Instituto Nacional de Controle de Qualidade em Saúde - INCQS/FIOCRUZ, Av. Brasil, 4365, Manguinhos, CEP 21040-900, Rio de Janeiro, RJ, Brasil,e-mail: marianadias.vet@gmail.com

${ }^{2}$ Laboratório de Microbiologia, Departamento de Tecnologia de Alimentos, Faculdade de Veterinária, Universidade Federal Fluminense - UFF, Rua Vital Brasil Filho, 64, Santa Rosa, CEP 24320-340, Niterói, RJ, Brasil

${ }^{*}$ Corresponding author 
cheese is considered an important source of income of farm families (EMPRESA..., 2004). Several outbreaks of foodborne diseases (FBD) associated with contaminated cheese have been reported worldwide (PASSOS et al., 2008).

The Technical Regulation which comprises food microbiological standards is Resolution $\mathrm{n}^{\circ} 12 / 2001$ (BRASIL, 2001). According to item 1.2.2 of appendix II, food which presents pathogenic microorganisms or toxins that pose risk to consumer health are considered improper to consumption. Water and food contamination by fecal bacteria represents a common and frequent issue resulting in impacts to public health and country economy (STEWART; SANTO DOMINGO; WADE, 2007).

Escherichia coli (E. coli), which belongs to the Enterobacteriaceae family, is a gram-negative, facultative anaerobic, non-sporulating bacteria. It is widely distributed in intestinal microbiota of humans and warm-blooded animals and in the environment, when contaminated with fecal elimination (NATARO; KAPER, 1998; SMITH; WILLSHAW; CHEASTY, 2004).

Generally, E. coli is a harmless commensal; however, several strains may show pathogenic features (NATARO; KAPER, 1998). Due to its great genetic diversity, it has remarkable ecologic plasticity, which makes $E$. coli able to quickly adapt to different environments and therefore able to undergo a transition from free-living life organism to a commensal organism of the intestinal tract of warm-blood animals and finally to a deadly pathogen in humans and animals (SOUZA et al., 1999).

According to the virulence mechanisms and set of signs and symptoms of the diseases caused, pathogenic E. coli strains are classified into six different pathotypes: enteropathogenic E. coli (EPEC), enterotoxigenic E. coli (ETEC), Shiga toxin producer E. coli (STEC)/enterohemorrhagic E. coli (EHEC), enteroaggregative E. coli (EAEC), enteroinvasive E. coli (EIEC), and diffuse adhesion producer E. coli (DAEC) (NATARO; KAPER, 1998; LÓPEZ-SAUCEDO et al., 2003). There are many serotypes of Stx-producing E. coli (STEC), but only those that have been clinically associated with hemorrhagic colitis are designated as EHEC. These pathogenic strains are commonly associated to endemic diarrhea in children (HUILAN et al., 1991). However, cases of diarrhea and mortality are not exclusive of developing countries. In the USA, 48 million cases of FBD are notified per year resulting in 128,000 hospitalizations and 3,000 deaths (SCALLAN, 2011).

All pathogenic E. coli strains have already been directly related to foodborne disease outbreaks, including meat, vegetables, milk, and dairy products affecting mainly children and immunocompromised individuals in general. The presence of pathogenic E. coli strains in Minas soft cheese has been reported by several studies (NASCIMENTO; SABIONI; PIMENTA, 1988; PANETO et al., 2007).

Several studies suggest that every pathogenic E. coli pathotype carries out one or more specific genes or a combination of virulence factors distinguishing them from nonpathogenic strains and other pathotypes (SHPIGEL et al., 2008). Genes encoding virulence factors are conserved among isolated samples from different continentes (ARANDA et al., 2007; BRANDAL et al., 2007). A substantial progress and development has been achieved based on nucleic acids analysis; thus the amplification of specific DNA sequences of those genes has been used as an appropriate tool for the challenging task of finding pathogenic E. coli in clinical samples (GÓMEZ-DUART et al., 2009) and food samples (LÓPEZ-SAUCEDO et al., 2003). Furthermore, another concern is the probability of human intestinal mucosa colonization by microorganisms which are resistant to the antimicrobial frequently used to treat illnesses caused by ingestion of contaminated food (DIAS et al., 2010).

Cases of pathogenic E. coli strains showing different resistance patterns (COSTA et al., 2006) and cases of multi-resistant strains (GUERRA et al., 2003; DIAS et al., 2010) have been reported.

Foods of animal origin are remarkably known as an important factor in the FBD chain. This study aimed to isolate, evaluate the antimicrobial susceptibility, and molecularly characterize, by Multiplex PCR, pathogenic E. coli strains isolated from Minas soft cheese commercialized in the Rio de Janeiro.

\section{Material and methods}

\subsection{Samples}

In the period from 2007 to 2009, thirty samples of Minas soft cheese were acquired. Among those, 22 samples had gone through Sanitary Inspection (municipal, state, or federal), and 8 were handmade samples. The samples were purchased from supermarkets located in Rio de Janeiro and local homemade product stores. Following acquisition, the samples were stored in individual packages, sealed, and taken to the laboratory under refrigeration. The analyses were conducted at the food microbiology department of the Instituto Nacional de Controle de Qualidade em Saúde (INCQS) - FIOCRUZ.

\subsection{Isolation, identification, and antimicrobial susceptibility evaluation of the pathogenic strains}

Isolation of pathogenic E. coli strains was performed according to the methodology described by Feng, Weagant and Jinneman (2003) in the Bacteriological Analytical Manual. From each sample, approximately 160 typical or atypical E. coli colonies were selected for microbial identification by biochemical tests, antimicrobial susceptibility evaluation, and molecular characterization.

The biochemistry identification of species and antimicrobial susceptibility evaluation were carried out using GNI and GNS cards, respectively, performed by the VITEK_32 semi-automatized system (BioMerieux). Susceptibility evaluation was based on the Clinical Laboratory Standards Institute (CLSI). The antimicrobials tested and their minimum inhibitory concentration (MIC), in $\mathrm{mcg} / \mathrm{mL}$ were: Amikacin (NA; 2), Ampicilin (AM; 32), Ampicilin-Sulbactan (MAS; 16), Azetreonam ( AZM; 8), Cefepime (FEP; 4), Cefotaxime (TAX; 4), Cefoxitin (FOX; 2), Ceftazidime (TAZ; 8), Cefalotin (CF; 
8), Ciprofloxacin (CIP; 0.5), Gentamicin (GM; 0.5), Imipenem (IMI; 4), Meropenem (MEM; 2), Piperacilin-Tazobactam (TZP; 8), and Trimethoprim-Sulfamethoxazole (STX; 10).

For this study, the selected E. coli colonies were streaked in "spots" onto trypticase soy agar (MERK) master-plates and incubated at $37^{\circ} \mathrm{C} / 24$ hours for further DNA extraction, purification, and molecular analysis.

\subsection{DNA extraction}

Isolation and purification of genomic DNA was performed using the DNeasy Tissue kit (QIAGEN) according to the manufacturer instructions. DNA samples were stored at $-20^{\circ} \mathrm{C}$.

\subsection{Molecular detection of virulence genes}

Purified DNA from isolated colonies previously extracted and stored at $-20{ }^{\circ} \mathrm{C}$ was used for molecular analysis. Reagents and primers used for the molecular characterization in this study were acquired from "Invitrogen Life Technologies" (São Paulo, SP, Brasil).

\subsection{Reference strains}

Five reference strains were used as positive controls; each belonging to a group of pathogenic E. coli: strains INCQS 00181 (CDC 055 - EPEC), INCQS 00171 (CDCEDL - 933 - EHEC) and INCQS 00170 (CDC EDL - 1284 - EIEC), from the Reference Culture Collection of Laboratório de Micro-orgamismos de Referência - INCQS/FIOCRUZ; strain 258909-3 ETEC (CFA/I ${ }^{+}$ 0128: H -; LT+/ST+), originated from Universidade do Estado do Rio de Janeiro (UERJ), and strain 2391 - EAEC originated from Instituto Adolfo Lutz - SP (IAL). A PCR reaction mix without DNA was used as negative control.

\subsection{Target genes and primers utilized}

Selected target genes and primers used for each pathogenic E. coli category were respectively: eae and SK1/SK2 for EPEC; st $x$ and Vtcom-u/Vtcom-d for STEC/EHEC; est/elt and EST-F/ EST-R, ELT-F/ELT-R for ETEC; aggR and aggRks1/aggRskas2 for EAEC; ipaH, and ipaIII/ipaIV for EIEC (Table 1). The eae gene codifies for Intimin, a protein which causes attachingand-effacing lesions; st $x$ gene codifies the Shiga-like toxin; elt and est genes that respectively codify the Thermolabile and Thermoestable toxins of enterotoxigenic E. coli; ipaH gene is associated with invasion capacity, and it is present in multiple copies in the plasmids and in EIEC chromosomes; aggR gene is a transcriptional activator of aggregative adherence fimbriae.

\subsection{Components and multiplex PCR conditions}

The M-PCR reaction was carried out based on Toma et al. (2003) and optimized in this study to allow the simultaneous amplification of all target genes. It was used a final volume of 50 $\mu \mathrm{L}$ containing 50-100 ng of DNA sample, 1 X PCR Buffer, $\mathrm{MgCl}_{2}$ (3.0 mM), 1 U of Taq DNA Polymerase dNTP mix $(0.3 \mathrm{mM})$, $1.250 \mu \mathrm{M}$ of SK1 and SK2 primers, $0.250 \mu \mathrm{M}$ of Vtcom-u and Vtcom-d primers, $0.500 \mu \mathrm{M}$ of EST-F and EST-R primers, $0.250 \mu \mathrm{M}$ of ELT-F and ELT-R primers, $0.100 \mu \mathrm{M}$ of ipaIII and ipaIV primers and $0.250 \mu \mathrm{M}$ of aggRks1, and aggRkas 2 primers.

Multiplex PCR was assembled with 30 amplification cycles at $95^{\circ} \mathrm{C}$ for 30 second; annealing at $50^{\circ} \mathrm{C}$ for 30 second; extension at $72{ }^{\circ} \mathrm{C}$ for 1 minute, and a final extension at $72{ }^{\circ} \mathrm{C}$ for 10 minutes.

PCR products were differentiated by molecular weight through a $2 \%$ agarose gel electrophoresis at $80 \mathrm{~V}$ for 2 hours in 1X TBE Buffer (Tris HCl $100 \mathrm{mM}$, boric acid 90 mM, EDTA $1 \mathrm{mM}, \mathrm{pH}$ 8,0). A 100 bp DNA ladder (Invitrogen, Carlsbad, CA, USA) was used as molecular weight pattern; the gels were stained with ethidium bromide $\left(0.5 \mu \mathrm{g} \cdot \mathrm{mL}^{-1}\right)$, visualized, and digitalized using Video Documentation System and analyzed with the ImageMaster software (Amersham Pharmacia Biotech).

\section{Results and discussion}

The data obtained in this study indicate the unsatisfactory hygienic-sanitary conditions of Minas soft cheese commercialized in the city of Rio de Janeiro. Since it is a ready-to-eat product made with raw components, this kind of cheese should be innocuous and not a potential health risk.

Table 1. Genes, primers and sequences used in the Multiplex PCR.

\begin{tabular}{|c|c|c|c|c|c|}
\hline Gene $^{\mathrm{a}}$ & "Primer" & Sequence $\left(5^{\prime}-3^{\prime}\right)$ & $\begin{array}{c}\text { Amplicon } \\
\text { (bp) }\end{array}$ & $\begin{array}{c}\text { Anel Temp. } \\
\left({ }^{\circ} \mathrm{C}\right)\end{array}$ & Reference \\
\hline \multirow[t]{2}{*}{ eae } & SK1 & CCCGAATTCGGCACAAGCATAAGC & 881 & 50 & Oswald et al. (2000) \\
\hline & SK2 & CCCGGATCCGTCTCGCCAGTATTCG & & & \\
\hline \multirow[t]{2}{*}{$s t x$} & Vtcom-u & GAGCGAAATAATTTATATGTG & 518 & 50 & Yamasaki et al. (1996) \\
\hline & Vtcom-d & TGATGATGGCAATTCAGTAT & & & \\
\hline \multirow[t]{2}{*}{ est } & EST-F & ATTTTTMTTTCTGTATTRTCTT & 190 & 50 & López-Saucedo et al. (2003) \\
\hline & EST-R & CACCCGGTACARGCAGGATT & & & \\
\hline \multirow[t]{2}{*}{ elt } & ELT-F & GGCGACAGATTATACCGTGC & 450 & 50 & López-Saucedo et al. (2003) \\
\hline & ELT-R & CGGTCTCTATATTCCCTGTT & & & \\
\hline \multirow[t]{2}{*}{$i p a H$} & ipaIII & GTTCCTTGACCGCCTTTCCGATACCGTC & 619 & 50 & Sethabutr et al. (1993) \\
\hline & ipaIV & GCCGGTCAGCCACCCTCTGAGAGTAC & & & \\
\hline \multirow[t]{2}{*}{$\operatorname{aggR}$} & aggRks1 & GTATACACAAAAGAAGGAAGC & 254 & 50 & Ratchtrachenchai et al. (1997) \\
\hline & aggRkas2 & ACAGAATCGTCAGCATCAGC & & & \\
\hline
\end{tabular}

1 - 100 bp DNA ladder; 2 - positive control. 
Isolated colonies from $100 \%$ of samples exhibited phenotypic characteristics which suggest $E$. coli identification. Similar data were described by Araujo et al. (2002) and Paneto et al. (2007), who reported extremely high contaminations of E. coli in Minas soft cheese, with isolation rates of $97 \%$ and $96 \%$ of samples respectively.

The visualization of simultaneous amplification of eae gene for EPEC; est and elt for ETEC; stx for STEC; aggR for EAEC, and $i p a H$ for EIEC used as positive controls can be observed in Figure 1. The amplification of eae gene for positive strains can be observed in Figure 2.

The molecular method used in the present study showed to be highly sensitive and specific to detect pathogenic E. coli strains originated from the studied samples, as documented by Paneto et al. (2007) and Stephan et al. (2008). From this Multiplex PCR, 5 enteropathogenic E. coli strains were molecularly identified.

According to the WHO (WORLD..., 2002), worldwide authorities have been intensifying their efforts to improve food security; however, pathogenic E. coli strains are still found in foods. After a foodborne outbreak caused by EPEC, the

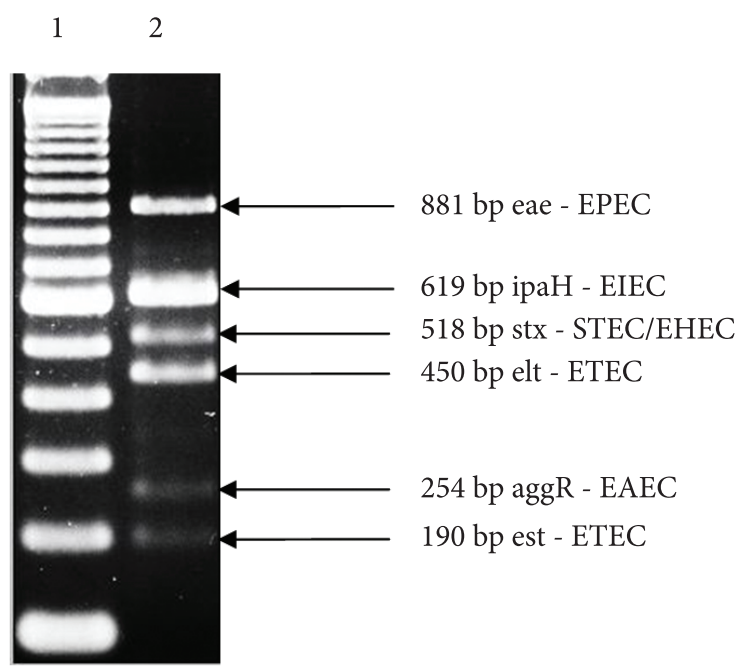

Figure 1. 2\% Agarose Gel Electrophoresis. Visualization of amplified genes used as positive controls in multiplex PCR.

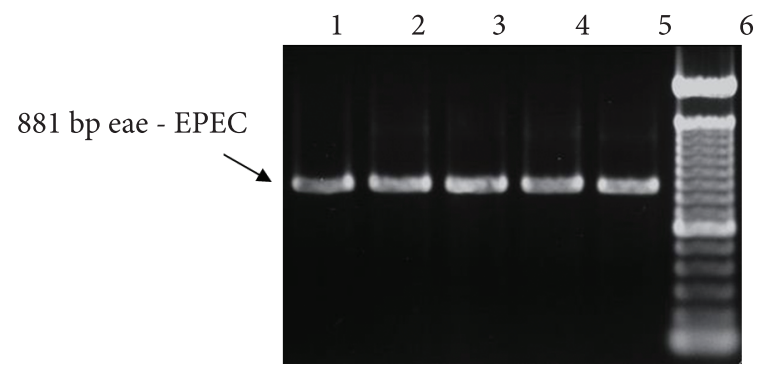

1-5 positive strains (MTD1, MTD2, MTD3, MTD4, MTD5) respectively;

6 - molecular weight (100 bp DNA ladder)

Figure 2. 2\% Agarose Gel Electrophoresis. Amplification of eae gene for positive strains. presence of this microorganism in cheeses has acquired a special significance (MARIER et al., 1973; PANETO et al., 2007).

In 1988, Nascimento, Sabioni and Pimenta (1988), analyzing several Minas soft cheese in Ouro Preto-MG, Brazil, advised against the presence of EPEC strains in this food. Even though, improvements regarding food security have been observed since then, EPEC has been isolated from this kind of cheese, as confirmed by the present study. Preliminary data were reported by Gonzalez et al. (2000), Araújo et al. (2002) and Schrade and Yager (2001) and others.

All 5 isolated EPEC strains were isolated from a handmade cheese sample corresponding to $12.5 \%$ of the total of handmade analyzed samples. Although handmade cheese production is considered an important economic activity, Bramley and McKinnon (1990) reported the hazard of product contamination by pathogenic microorganisms affecting both product quality and consumer health (FURTADO, 1991).

Domestic animals from different species have been investigated as natural reservoirs of pathogenic E. coli strains. Several studies have highlighted the importance of cattle, swine, and ovine, which are considered the most common species involved in this kind of transmission (GLADYS; SONJA; LOTHAR, 2005). China et al. (1999) and Dias (2007) reported the presence of AEEC (attaching and effacing E. coli, atypical EPEC strains, isolated mainly from animals) strains with pathogenic profile in healthy bovines, which may be an important issue of health security since these animals are used for meat and milk production. According to Dias (2007), atypical EPEC strains show a compatible virulence profile in animals and humans because of the similarity of phenotypic and genotypic markers detected.

Similar results were reported by Ahmed, Ahmed and Moustafa (1988) and Najand and Ghanbarpour (2006), who noted the presence of EPEC in handmade cheese samples. Other pathogenic E. coli strains have also been reported in this product, such as ETEC and VETEC (PANETO et al., 2007), EAEC (SCAVIA et al., 2008), and STEC (STEPHAN et al., 2008).

Our results are in agreement with those of research reports worldwide, such as Araújo et al. (2002), Najand and Ghanbarpour (2006) and Planzer Junior et al. (2009), emphasizing the danger that cheese production from unpasteurized milk presents.

Among the isolated EPEC strains, 40\% showed ampicillin resistance and $40 \%$ intermediary resistance profile to ampicillin-sulbactam association. Although multi-resistance E. coli cases have been reported (BACCARO et al., 2002; GUERRA et al., 2003; DIAS et al., 2010), such feature was not observed in this study.

High resistance to ampicillin was described by Baccaro et al. (2002) and Blanco et al. (2006); however, Dias et al. (2010) found only $2.27 \%$ of resistance to this antimicrobial. The E. coli strains isolated by Paneto et al. (2007) in Minas soft cheese showed higher cephalothin resistance (69\%) and only $29 \%$ to ampicillin. In this study, the resistance to cephalothin was not observed. To Baccaro et al. (2002), resistance to the association trimethoprim-sulfamethoxazole 
Dias et al.

Table 2. Antimicrobial susceptibility, ESBL presence and motility test of isolated EPEC.

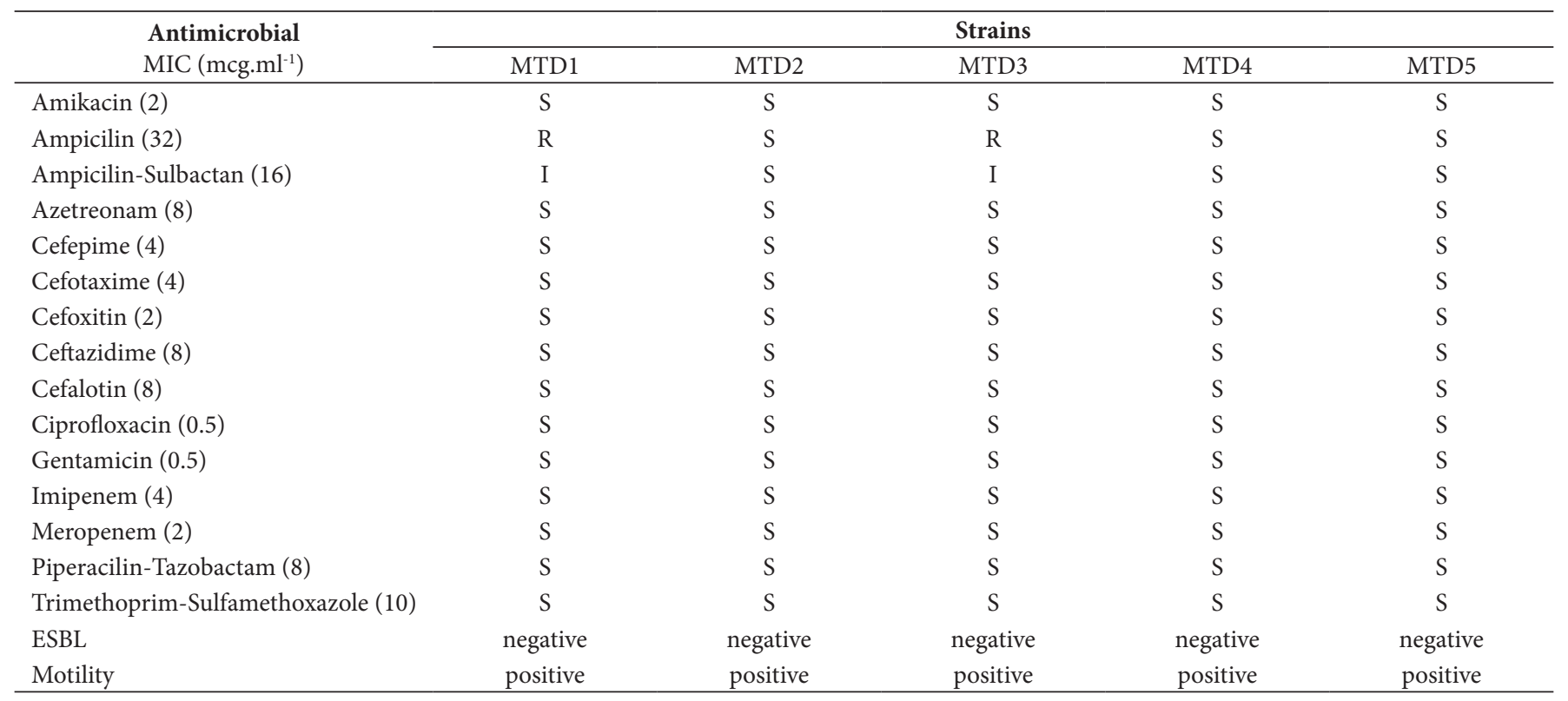

(87.4\%) was similar to ampicillin (86.8\%). Costa et al. (2006) also observed a high resistance $(73.5 \%)$ to the association trimethoprim-sulfamethoxazole, which was not observed in this study since $100 \%$ of the strains were sensible to these agents.

Some authors have associated beta-lactamase production with an increase in antimicrobial resistance (FERREIRA et al., 2006). The selective pressure exerted by antimicrobials such as beta-lactams compounds is related to the selection of resistant strains including extended spectrum beta-lactamase producing enterobacteria (ESBL) (CHOI et al., 2008). Emery and Weymouth (1997) demonstrated the existence of ESBL producing E. coli.

The extended spectrum beta-lactamase enzymes are capable to inactivate drugs such as ceftazidime and cefotaxime. In this study, it was observed $100 \%$ of sensibility to these antimicrobials, an expected result since ESBL strains were found to be negative.

The ampicillin-sulbactam association has been considered a potent inhibitor of beta-lactamases, which can inactivate this resistance (FERREIRA et al., 2006). In this study, $40 \%$ of the isolates showed intermediate resistance profile to these antimicrobials. However, resistant strains to this association have been observed, as showed by Nascimento et al. (2009), who found resistance to ampicillin-sulbactam of $75.6 \%$. The results of antimicrobial susceptibility evaluation are described in Table 2.

Dias et al. (2010) reported that E. coli strains show high variability and high capacity to acquire resistance genes according to Gonçalves (2009). This association of factors can explain the divergences observed in the study of this microorganism.

\section{Conclusions}

All isolates analyzed were phenotypically classified as Escherichia coli. The presence of EPEC strains in Minas soft cheese represents an important risk factor to public health; the quality of raw material and hygienic-sanitary aspects are essential for product safety.

It was noted that the use of multiplex PCR optimized in this study is an effective tool to identify pathogenic E. coli strains in Minas soft cheese.

The ingestion of products contaminated with EPEC strains, such as those identified in this study, may cause the colonization of intestinal tract by antimicrobial resistant strains.

The results found are alarming since the analyzed product is ready for consumption and frequently used in hospital diets; therefore, the Minas soft cheese must be innocuous, and should not pose potential health risk.

The commercialization of milk and its derivatives without any kind of inspection, a typical countryside tradition in the past, is nowadays present in the small commerce and markets in Rio de Janeiro. Although there is no legal authorization for this commercialization, people who consume these products regularly get sick frequently. This may suggest that integrated actions among research, inspection, and extension centers associated with effective public policies could make milk and dairy production a viable, safe, and sustainable activity.

\section{Acknowledgement}

The authors are grateful to the Instituto Nacional de Controle de Qualidade em Saúde - INCQS/FIOCRUZ, for the laboratory facilities and to CAPES for the financial support.

\section{References}

AHMED, A.; AHMED, H.; MOUSTAFA, K. Occurrence of fecal colifom and enteropathogenic Escherichia coli (EEC) in Egyption soft cheese. Journal of food protection, v. 51, n. 6, p. 422-443, 1988. 
ARANDA, K. R. S. et al. Single multiplex assay to identify simultaneously enteropathogenic, enteroaggregative, enterotoxigenic,enteroinvasive and Shiga toxin-producing Escherichia coli strains in Brazilian children. FEMS Microbiology Letters, v. 267, n. 2, p. 145-150, 2007. PMid:17328113. http://dx.doi. org/10.1111/j.1574-6968.2006.00580.x

ARAÚJO, V. S. et al. Occurrence Staphylococcus and enteropathogens in soft cheese commercialized in the city of Rio de Janeiro, Brazil. Journal of Applied Microbiology, v. 92, p. 1172-1177. 2002. PMid:12010558. http://dx.doi.org/10.1046/j.1365-2672.2002.01656.x

BACCARO, M. R. et al. Resistência antimicrobiana de amostras de Escherichia coli isoladas de fezes de leitões com diarréia. Arquivos do Instituto Biológico, v. 69, n. 2, p. 15-18, 2002.

BLANCO, J. et al. Escherichia coli patógenos para seres humanos y animals. Laboratorio de referencia de E. coli (LREC). Disponível em: <www.lugo.USC.ES/ecoli/E.coli.html>. Acesso em: 15 jan. 2006.

BRAMLEY, A. J.; McKINNOM, C. H. Dairy microbiology: the microbiology of milk. 2nd ed. London; New York: Elsevier Science Ltda, 1990. p. 163-207.

BRANDAL, V. et al. Octaplex PCR and fluorescence- based capillary electrophoresis for identification of human diarrheagenic Escherichia coli and Shigella spp. Journal of Microbiological Methods, v. 68, n. 2, p. 331-341, 2007. PMid:17079041. http://dx.doi. org/10.1016/j.mimet.2006.09.013

BRASIL. Ministério da Agricultura, Pecuária e Abastecimento. Regulamento da Inspeção Industrial e Sanitária de Produtos de Origem Animal (RIISPOA). Brasília: MAPA, 1974. p.138-209.

BRASIL. Ministério da Agricultura, Pecuária e Abastecimento. Portaria no 352, de 04 de setembro de 1997. Regulamento Técnico para Fixação de Identidade e Qualidade de Queijo Minas Frescal. Diário Oficial da República Federativa do Brasil, Brasília, DF, 08 set. 1997.3 p.

BRASIL. Ministério da Saúde. Resolução nº 12, de 02 de janeiro de 2001. Regulamento Técnico sobre Padrões Microbiológicos para Alimentos. Diário Oficial da República Federativa do Brasil, Brasília, DF, 03 jan. 2001. Seção 1, pt. 1.

CHINA, B. et al. Comparasion of eae, tir, espA and espB genes of bovine and human "attaching and effacing" Escherichia coli by multiplex polymerase chain reaction. FEMS Microbiology Letters, v. 178, n. 1, 177-182, 1999. PMid:10483737. http://dx.doi. org/10.1111/j.1574-6968.1999.tb13775.x

CHOI, S. H. et al. Emergence of antibiotic resistance during therapy for infections caused by Enterobacteriaceae producing AmpC $\beta$-lactamase: implications for antibiotic use. Antimicrobial Agents and Chemotherapy, v. 52, n. 3, p. 995-1000, 2008. PMid:18086837 PMCid:2258504. http://dx.doi.org/10.1128/AAC.01083-07

COSTA, M. M. et al. Caracterização epidemiológica, molecular e per perfil fil de resistência aos antimicrobianos de Escherichia coli isoladas de criatórios suínos do sul do Brasil. Pesquisa Veterinária Brasileira, v. 26, n. 1, p. 5-8, jan./mar. 2006. http://dx.doi. org/10.1590/S0100-736X2006000100002

DIAS, M. T. Caracterização fenotípica e genotípica de Escherichia coli produtora da lesão "attaching and effacing" (AEEC) isoladas de amostras fecais de bovinos sadios. 2007. 80 f. Dissertação (Mestre em clínica Veterinária)-Faculdade de Veterinária, Universidade Federal Fluminense, Niterói, 2007.

DIAS, M. T. et al. Avaliação da sensibilidade de cepas de Escherichia coli isoladas de mexilhões (Perna perna linnaeus, 1758) à antimicrobianos. Ciência e Tecnologia de Alimentos, v. 30, n. 2, p. 319-324, 2010. http://dx.doi.org/10.1590/S010120612010000200005
EMPRESA DE ASSISTÊNCIA TÉCNICA E EXTENSÃO RURAL - EMATER. Queijos tradicionais de Minas com mais qualidade. Revista da EMATER, v. 22, n. 80, p. 8-9, ago. 2004.

EMERY, C. L.; WEYMOUTH, L. A. Detection and clinical signification of extended spectrum $\beta$-lactamases in Tertiary Care medical Center. Journal of Clinical Microbiology, v. 35, n. 8, p. 2061-2067, 1997. PMid:9230382 PMCid:229903.

FENG, P.; WEAGANT, S. D.; JINNEMAN, K. Diarrheagenic Escherichia coli. In: FOOD AND DRUG ADMINISTRATION - FDA. Bacteriological Analytical Manual. FDA, 2003. cap. 4A.

FERREIRA, J. B. et al. Eficácia e segurança de Sultamicilina (Ampicilina/Sulbactam) e Amoxacilina/ Clavulanato no tratamento das infecções de via aéreas superiores em adultos - um estudo multicêntrico, aberto e randomizado. Revista Brasileira de Otorrinolaringologia, v. 72, n. 1, p. 104-11, 2006. PMid:16917560. http://dx.doi.org/10.1590/S0034-72992006000100016

FREITAS, A. C. et al. Ocurrence and characterization of Aeromonas species in pasteurized milk and white cheese in Rio de Janeiro, Brasil. Journal of Food Protection, v. 5, n. 1, p. 62-65, 1993.

FURTADO, M. M. A Arte e a Ciência do Queijo. 2. ed. São Paulo: Globo, 1991.

GLADYS, K.; SONJA , Z.; LOTHAR, B. Investigation of domestic animals and pets as a reservoir for intimin - (eae) gene positive Escherichia coli types. Veterinary Microbiology, v. 106, n. 1-2, p. 87-95, 2005. PMid:15737477. http://dx.doi.org/10.1016/j. vetmic.2004.11.012

GÓMEZ-DUART, O. G. et al. Detection of Escherichia coli enteropathogens by multiplex polymerase chain reaction fron children's diarrheal stool in two Caribbean-Colombian cities. Diagnostic Microbiology and Infectious Disease, v. 7, n. 2, p. 199-206, 2009.

GONÇALVES, A. F. Análise molecular da resistência a antibióticos, factores de virulência e grupos filogenéticos em Escherichia coli e Enterococcus spp. de animais. 2009. 95 f. Dissertação (Mestre em Biologia Clínica Laboratorial)-Universidade de Trás-os-Montes e Alto Douro, Vila Real, 2009.

GONZALEZ, A. G. M. et al. Enteropathogenicity markers in Escherichia coli strains isolated from soft white cheese and poultry in Rio de Janeiro, Brazil. Food Microbiology, v. 17, n. 3, p. 321-328, 2000. http://dx.doi.org/10.1006/fmic.1999.0320

GUERRA, B. et al. Phenotypic and genotypic characterization of antimicrobial resistance in German Escherichia coli isolates from cattle, swine and poultry. Journal of Antimicrobial Chemotherapy, v. 52, n.3, p. 489-492, 2003. PMid:12888584. http://dx.doi. org/10.1093/jac/dkg362

HUILAN, S. et al. Etiology of acute diarrhoea among children in developing countries: a multicentre study in five countries. Bulletin of the World Health Organization, v. 69, n. 5, p. 549-555, 1991. PMid:1659953 PMCid:2393250.

LÓPEZ-SAUCEDO, C. et al. Single multiplex polimerase chain reaction to detect diverse loci associated with diarrheagenic Escherichia coli. Emerging Infectious Diseases, v. 9, n. 1, p. 127-131, 2003. http:// dx.doi.org/10.3201/eid0901.010507

MARIER, R. et al. An outbreak of enteropathogenic Escherichia coli food borne disease traced to imported fresh cheese. Lancet, v. 2, p. 1376-1378, 1973. http://dx.doi.org/10.1016/S01406736(73)93335-7

NAJAND, L. M.; GHANBARPOUR, R. A study on enteropathogenic Escherichia coli isolated from domestic Iranian soft cheese. Veterinarski Archiv, v. 76, n. 6, p. 531-536, 2006. 
NASCIMENTO, D.; SABIONI, J. G.; PIMENTA, N. Freqüência de Escherichia coli enteropatogênica clássica (EPEC) e enteroinvasora (EIEC) em queijo tipo Minas-Frescal da cidade de Ouro Preto. Revista de Microbiologia, v. 19, p. 258-61, 1988.

NASCIMENTO, T. C. et al. Ocorrência de bactérias clinicamente relevantes nos resíduos de serviços de saúde em um aterro sanitário brasileiro e perfil de susceptibilidade a antimicrobianos. Revista da Sociedade Brasileira de Medicina Tropical, v. 42, n. 4 , p. 415-419, 2009. PMid:19802478. http://dx.doi.org/10.1590/S003786822009000400011

NATARO, J. P.; KAPER, J. B. Diarrheagenic Escherichia coli. Clinical Microbiology Reviews, v. 11, n. 1, p. 142-201, 1998. PMid:9457432 PMCid:121379.

OSWALD, E. et al. Typing of intimin genes in human and animal enterohemorrhagic and enteropathogenic Escherichia coli: characterization of a new intimin variant. Infection and Immunity, v. 68, n. 1, p. 64-71, 2000. PMid:10603369 PMCid:97102. http:// dx.doi.org/10.1128/IAI.68.1.64-71.2000

PANETO, B. R. et al. Ocorrência de Escherichia coli toxigênica em queijo minas frescal no Brasil. Arquivo Brasileiro de Medicina Veterinária e Zootecnia, v. 59, n. 2, p. 508-512, 2007. http://dx.doi. org/10.1590/S0102-09352007000200035

PASSOS, E. C. et al. Surto de toxinfecção alimentar em funcionários de uma empreiteira da construção civil no município de Cubatão, São Paulo/Brasil. Revista Instituto Adolfo Lutz, v. 67, n. 3, p. 237-240, 2008.

PLANZER JUNIOR, S. B. et al. Food Safety Knowledge of Cheese Consumers. Journal of Food Science, v. 74, n. 1, 2009.

RATCHTRACHENCHAI, O. A. et al. Investigation on enteroaggregative Escherichia coli infection by multiplex PCR. Bulletin of the Department of Medical Sciences, v. 39, p. 211-220, 1997.

SCALLAN, E. et al. Foodborne illness acquired in the United States - unspecified agents. Emerging Infectious Diseases, v. 17, p. 16-22, 2011. PMid:21192849 PMCid:3204615.

SCAVIA, G. et al. Enteroaggregative Escherichia coli associated with a foodborne outbreak of gastroenteritis. Journal of Medical Microbiology, v. 57, p. 1141-1146, 2008. PMid:18719185. http:// dx.doi.org/10.1099/jmm.0.2008/001362-0

SCHRADE, J. P.; YAGER, J. Implication of milk and milk products in food disease in France and in different industrialized countries.
International Journal of Food Microbiology, v. 67, p. 1-17, 2001. http://dx.doi.org/10.1016/S0168-1605(01)00443-3

SETHABUTR, O. et al. Detection of Shigellae and enteroinvasive Escherichia coli by amplification of the invasion plasmid antigen H DNA sequence in patients with dysentery. Journal of Infectious Diseases, v. 167, p. 458-461, 1993. PMid:8421181. http://dx.doi. org/10.1093/infdis/167.2.458

SILVA, S.; SOUZA, C. Avaliação microbiológica de queijo tipo minas frescal comercializado na cidade de Belém-Pará. Laboratório Central do Estado do Pará, Centro Tecnológico da Universidade Federal do Pará, 2006. PMid:18291708.

SHPIGEL, N. Y. et al. Mammary pathogenic Escherichia coli. Current opinion in microbiology, v. 11, n. 1. p. 60-65, 2008. http://dx.doi. org/10.1016/j.mib.2008.01.004

SMITH, H.; WILLSHAW, G.; CHEASTY, T. E. coli as a cause of outbreaks of diarrhoeal disease in the UK. Microbiology Today, v. 31, p. 117-118, 2004. PMid:10427022 PMCid:91507.

SOUZA, V. M. et al. Genetic structure of natural populations of Escherichia coli in wild hosts on different continents. Applied and Environmental Microbiology, v. 65, n. 8, p. 3373-3385, 1999. PMid:18565913.

STEPHAN, R. et al. Prevalence and characteristics of Shiga toxin-producing Escherichia coli in Swiss raw milk cheeses collected at producer level. Journal of Dairy Science, v. 91, n. 7, p. 2561-2565, 2008. http://dx.doi.org/10.3168/jds.2008-1055

STEWART, J.; SANTO DOMINGO, J. W.; WADE, T. J. Fecal pollution, public health, and microbial source tracking. In: SANTO DOMINGO, J. W.; SADOWSKY, M. J. (Eds.). Microbial Source Tracking. Washington: ASM Prress, 2007. p. 1-32. PMid:12791900 PMCid:156568.

TOMA, C. et al. Multiplex PCR Assay for Identification of Human Diarrheagenic Escherichia coli. Journal of Clinical Microbiology, v. 41, n. 6, p. 2669-2671, 2003. PMid:8999287. http://dx.doi. org/10.1128/JCM.41.6.2669-2671.2003

YAMASAKI, S. et al. Typing of verotoxins by DNA colony hybridization with poly - and oligonucleotide probes, a bead-enzymelinked immunosorbent assay, and polymerase chain reaction. Microbiology and Immunology, v. 40, n. 5, p.345-352, 1996.

WORLD HEALTH ORGANIZATION - WHO. Global strategy for food safety: safer food for better health. Food safety issues, 2002. 